\title{
Pengaruh Berpikir Kausalitik Ber-Scaffolding Terhadap Kemampuan Pemecahan-Masalah Kalor pada Siswa SMA
}

\author{
Ina Yuliana ${ }^{1}$, Joni Rokhmat ${ }^{2}$, I Wayan Gunada ${ }^{3}$ \\ Program Studi Pendidikan Fisika, FKIP, Universitas Mataram, \\ Jl. Majapahit no 62 Mataram \\ Email : inayulianaikhsan@gmail.com
}

\begin{abstract}
Causalitical thinking consists of causality and analytics thinking. Both are one of the strategies that have the potential to facilitate students to overcome the ability of problem solving physics is still lacking. This research aimed to identify the impact of causalitic-thinking process in scaffolding form on problem-solving ability (PSA) of heat on senior high school (SHS) students. This research is a quasi-experimental type with non-equivalent control group design. This research used purposive sampling technique and it obtained the class X.1 (27) as the experimental class and class $X .2$ (28) as the control class. The PSA data were obtained from a set essay tests and tested with t-test polled variance with significant level of $5 \%$. The result was that $t_{\text {counted }}(2.02)$ greater than that of $t_{\text {table }}$ (2.00) which indicated that the causalitic-thinking process in scaffolding form significantly increased the problem-solving ability of heat on senior high school students.
\end{abstract}

Keywords: Causalitic-thinking, scaffolding, problem-solving ability, heat

\begin{abstract}
Abstrak: Berpikir Kausalitik terdiri dari berpikir kausalitas dan analitik. Keduanya merupakan salah satu strategi yang berpotensi memfasilitasi siswa untuk mengatasi kurang berkembangnya kemampuan pemecahan masalah fisika siswa. Penelitian ini bertujuan untuk mengidentifikasi pengaruh proses berpikir kausalitik ber-scaffolding terhadap kemampuan pemecahan-masalah (KPM) kalor pada siswa sekolah menengah atas (SMA). Jenis penelitian ini adalah quasi eksperimental dengan desain nonequivalent control group design. Sampel diambil dengan menggunakan teknik purposive sampling, sehingga diperoleh kelas X.1 (27) sebagai kelas eksperimen dan kelas X.2 (28) sebagai kelas kontrol. Data penelitian diperoleh dari tes KPM yang berbentuk essai. Data hasil dianalisis menggunakan uji-t polled varian dengan taraf signifikan $5 \%$ dan diperoleh nilai $t_{\text {hitung }}(2.02)$ lebih besar dari $t_{\text {table }}(2.00)$. Simpulan penilitian adalah bahwa proses berpikir kausalitik ber-scaffolding secara signifikan meningkatkan kemampuan-pemecahan-masalah siswa SMA pada materi kalor.
\end{abstract}

Kata kunci: Berpikir-kausalitik, scaffolding, kemampuan pemecahan-masalah, kalor

\section{PENDAHULUAN}

Ilmu pengetahuan dan teknologi mengalami perkembangan yang cukup pesat yang mempengaruhi perkembangan di segala bidang kehidupan dan pembangunan. Oleh karena itu, ilmu pengetahuan dan teknologi perlu ditingkatkan dan diarahkan untuk meningkatkan kecerdasan dan kesejahteraan masyarakat. Salah satu caranya, yaitu dengan memperhatikan pendidikan.

Titik berat pembanguanan dibidang pendidikan diletakkan pada peningkatan mutu pendidikan setiap jenjang dan jenis pendidikan [1]. Mutu pendidikan akan mampu ditingkatkan, salah satunya dengan memperhatikan proses pembelajaran. Komponenkomponen yang terkait dalam proses pembelajaran itu diantaranya fasilitas, guru, dan siswa. Jadi sejalan dengan itu proses penyiapan kemampuan siswa merupakan bagian yang penting untuk mampu meningkatkan mutu pendidikan. 
Proses pembelajaran fisika di kelas masih menghadapi beberapa masalah. Salah satunya adalah bahwa pendekatan dalam pembelajaran masih didominasi peran guru (teacher centered). Pembelajaran yang bersifat teacher centered adalah pembelajaran yang lebih banyak menempatkan peserta didik sebagai objek dan bukan sebagai subjek didik [2]. Dalam proses pembelajaran siswa kurang diberikan kesempatan untuk mengembangkan kemampuan berpikir terbuka, sehingga berdampak pada kemampuan pemecahan-masalah (KPM) fisika dari siswa yang rendah. Di sisi lain, beberapa dampak dari pembelajaran seperti itu juga terlihat ketika pembelajar dalam menyelesaikan fenomena atau persoalan fisika sering mengalami kesulitan, seperti tidak dapat: 1) menentukan elemen fenomena 4 yang mana sebagai suatu faktor atau penyebab, 2) memprediksi akibat-akibat yang berkemungkinan terjadi, 3) membedakan penyebab-penyebab yang terkait dan yang tidak terkait dengan suatu akibat tertentu, 4) menentukan konsep, prinsip, teori, dan/atau hukum fisika yang terkait dengan peristiwa terjadinya suatu akibat, 5) menerapkan konsep, prinsip, teori, dan/atau hukum fisika tersebut untuk menjelaskan terjadinya suatu akibat, dan 6) mengidentifikasi kondisi setiap penyebab terkait sehingga suatu akibat tertentu terjadi [6]. Kemampuan pemecahan-masalah memerlukan suatu keterampilan dan kemampuan khusus yang dimiliki masing-masing siswa, yang mungkin akan berbeda antar siswa dalam menyelesaikan suatu masalah. Kemampuan pemecahan-masalah mengacu pada upaya yang diperlukan siswa dalam menentukan solusi atas masalah yang dihadapi [3]. Untuk itu diperlukan strategi yang dapat meningkatkan KPM ini, salah satunya melalui proses berpikir kausalitik (PBK).

Proses berpikir-kausalitik (PBK) terdiri dari berpikir kausalitas dan analitik. Integrasi dari kedua berpikir tersebut menjadi sebuah strategi baru dalam fisika yang dipadukan dalam kinerja pemecahan-masalah yang berpotensi memfasilitasi siswa untuk mengatasi kurang berkembangnya kemampuan pemecahan-masalah fisika [4 \& 5].

Penelitian terkait yang dilakukan oleh Rokhmat, dkk. (2012) [4], Rokhmat $(2013,2015)$ [6, 7], Rokhmat, dkk. $(2015,2016,2017)$ [8, 9, \& 10] melalui penerapan proses berpikirkausalitik mampu meningkatkan kemampuan pemecahan-masalah fisika mahasiswa. Fakta tersebut diprediksi juga akan terjadi jika PBK diimplementasikan pada siswa dengan bantuan lembar kerja siswa (LKS) yang berbantuan tahapan (PBK ber-scaffolding) yang sudah dirancang sedemikian rupa untuk terbiasa berpikir secara terbuka.

PBK berbantuan LKS yang ber-scaffolding merupakan proses berpikir kausalitas dan analitik siswa melalui LKS yang diberikan bantuan tahapan dengan porsi tertentu. Rokhmat (2013) [6] memperkenalkan delapan instrumen Pengembangan Berpikir Kausalitik (PBK) ber-scaffolding, yaitu dari pola PBK ber-scaffolding tipe 1a hingga $4 \mathrm{a}$ dan $1 \mathrm{~b}$ hingga $4 \mathrm{~b}$. LKS yang digunakan secara umum adalah LKS ber-scaffolding tipe $2 \mathrm{~b}$ yang sudah terbukti efektif dan efisien dalam meningkatkan kemampuan pemecahan masalah.

Bantuan yang diberikan dalam LKS ber-scaffolding tipe $2 \mathrm{~b}$, yaitu bantuan pola utama tabel kausalitas, sebagian akibat dalam tabel tersebut dan sebagian penjelasannya sudah diberikan. Kemudian siswa diminta menentukan komponenkomponen penyebab dan akibat lainnya dengan jumlah yang sudah diketahui dari suatu fenomena fisika. Selanjutnya siswa tersebut diminta memberi penjelasan bagaimana penyebab-penyebab itu dapat menghasilkan setiap akibat. Dalam pola PBK ber-scaffolding tipe $2 \mathrm{~b}$ ini tidak diberikan bantuan pada komponen penyebabnya. Untuk itu akan lebih optimal lagi apabila PBK diimplementasikan dengan berbantuan LKS ber-scaffolding tipe $2 \mathrm{~b}$ yang dimodifikasi.

PBK berbantuan LKS yang ber-scaffolding tipe $2 \mathrm{~b}$ modifikasi merupakan hasil modifikasi dari PBK ber-scaffolding tipe $2 b$ berbantuan LKS yang di dalamnya terdapat proses berpikirkausalitik yang diberikan pada siswa melalui LKS dengan bantuan hanya berupa sebagian akibat dalam tabel kausalitas dan sebagian penjelasannya, sedangkan komponen penyebabnya tidak diberikan bantuan tahapan. Selanjutnya format PBK tersebut dimodifikasi dengan 
memberitahukan sebagian komopnen penyebab sebagian bantuan tambahan. Kemudian siswa diminta melengkapi seluruh komponen penyebab, akibat, serta penjelasan lainnya dengan jumlah yang sudah diketahui.

\section{METODE PENELITIAN}

Penelitian ini dilakukan pada siswa kelas X disalah satu Sekolah Menengah Atas Negeri di kabupaten Lombok Tengah yang berjumlah 55 orang, 28 di kelas kontrol dan 27 orang di kelas eksperimen. Penelitian ini dilakukan dengan desain non-equivalent control group. Perlakuan dilakukan pada kelas eksperimen yang berlangsung selama 6 kali tatap muka@45 menit. Pada kelas kontrol diterapkan pembelajaran konvensional dengan jumlah tatap muka dan durasi yang sama. Instrument yang digunakan meliputi: (1) LKS ber-scaffolding tipe 2b modifikasi, (2) alat tes kemampuan pemecahan masalah, (3) silabus, (4) RPP, dan (5) kisi-kisi instrumen. Analisis instrumen meliputi: validasi ahli dan validasi empiris. Instrumen yang dilakukan validasi ahli ini meliputi konstruksi, isi, dan bahasa untuk LKS, alat tes kemampuan pemecahan masalah, dan RPP. Sedangkan instrumen yang dilakukan validasi empiris, yaitu alat tes kemampuan pemecahan masalah yang dilakukan melalui tahap uji coba kepada siswa yang telah mempelajari materi suhu dan kalor. Data KPM diperoleh dari hasil tes awal dan tes akhir menggunakan soal uraian. KPM tersebut meliputi IPM-1 understanding, IPM-2 selecting, IPM-3 differentiating, IPM-4 determining, IPM-5 applying, dan IPM-6 identifying [4, 5, 6, 7, 8, 9, \& 10]. Penelitian ini dibatasi pada materi kalor. Pengolahan data diawali dari pengujian homogenitas dan normalitas data. Kemudian pengujian hipotesis dengan $t$-test polled varian pada taraf signifikansi $5 \%$.

\section{HASIL DAN PEMBAHASAN}

\subsection{Hasil}

Data KPM diperoleh dari hasil tes awal (pre-test) dan hasil tes akhir (post-test) fisika siswa kelas eksperimen dan kelas kontrol (Gambar 1).

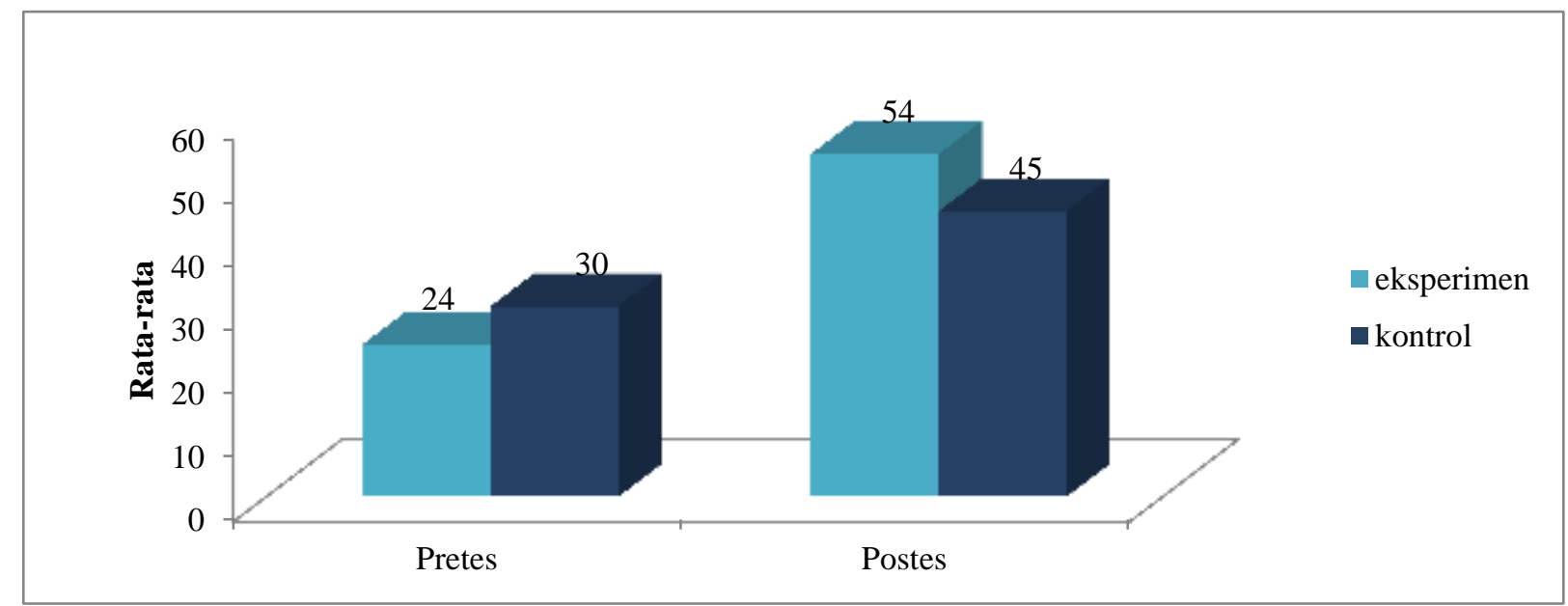

Gambar 1. Diagram Skor Kemampuan Pemecahan Masalah Fisika Siswa Kelas Eksperimen dan Kelas Kontrol

Gambar 1 menunjukkan bahwa kelas eksperimen yang diberikan perlakuan PBK berscaffolding tipe $2 \mathrm{~b}$ modifikasi yang berbantuan LKS memperoleh skor rata-rata yang lebih tinggi dibanding kelas kontrol yang tidak diberi perlakuan tersebut. Pada grafik, terlihat 
bahwa peningkatan nilai rata-rata setelah diberi perlakuan untuk kelas eksperimen sebesar 30 (dari 24 menjadi 54) sedangkan pada kelas kontrol peningkatan nilai rata-ratanya adalah 15 (dari 30 menjadi 45), jadi peningkatan nilai rata-rata kelas eksperimen lebih tinggi daripada kelas kontrol. Data KPM fisika siswa jika dikaitkan dengan keenam indikator yang merupakan aspek KPM yang harus dicapai siswa (understanding, selecting, differentiating, determining, applying, dan identifying) diperoleh nilai rata-rata KPM fisika siswa untuk masing-masing indikator berbeda. IPM-5 applying dan IPM-6 identifying merupakan aspek yang sulit dicapai siswa dibandingkan dengan indikator lainnya (Tabel 1). Pengujian data diawali dari pengujian homogenitas data tes awal dan normalitas data tes akhir untuk menentukan jenis uji- $t$ yang digunakan. Hasil uji homogenitas tes awal kedua kelas menunjukan $F_{\text {hitung }}(1,23)$ lebih kecil dari $F_{\text {tabel }}(1,88)$ yang berarti bahwa dengan taraf signifikansi $5 \%$, siswa pada eksperimen dan kelas kontrol adalah homogen (Tabel 2). Selanjutnya, hasil uji normalitas pada masingmasing kelas menunjukkan nilai $x^{2}$ hitung untuk kelas eksperimen $(11,2603)$ dan kelas kontrol $(4,7167)$ lebih kecil dari $x_{\text {tabel }}^{2}(12,592)$ yang berarti bahwa dengan taraf signifikansi $5 \%$, data KPM pada kelas eksperimen maupun kelas kontrol masing-masing adalah terdistribusi normal (Tabel 3). Dengan kondisi ini, statistik parametrik dapat digunakan untuk uji hipotesis dan data yang digunakan untuk uji tersebut dapat diambil dari hasil post-test saja. Sementara itu, hasil uji-t, menunjukkan bahwa nilai $t_{\text {hitung }}(2,02)$ lebih besar dari $t_{\text {tabel }}(2,00)$ yang berarti bahwa dengan taraf signifikansi 5\%, skor akhir KPM pada siswa kelas eksperimen dan kelas kontrol adalah berbeda (Tabel 4). Jika hasil uji ini dikaitkan dengan rata-rata skor akhir KPM kelas eksperimen (54) yang lebih tinggi daripada kelas kontrol (45) (Gambar 1) maka dapat diartikan bahwa implementasi pembelajaran dengan proses berpikir-kausalitik ber-scaffolding tersebut berpengaruh positip terhadap KPM siswa pada materi panas.

Tabel 1.Nilai Rata-rata Kemampuan Pemecahan Masalah (KPM) Tiap Indikator

\begin{tabular}{|c|c|c|c|c|c|c|c|}
\hline \multirow{2}{*}{ Kelas } & \multirow{2}{*}{ Kemampuan } & \multicolumn{6}{|c|}{ Rata-rata Kemampuan Pemecahan Masalah (\%) } \\
\hline & & IPM-1 & IPM-2 & IPM-3 & IPM-4 & IPM-5 & IPM-6 \\
\hline Eksperimen & \multirow{2}{*}{ Awal } & 69 & 31 & 2 & 27 & 6 & 0 \\
\hline Kontrol & & 85 & 37 & 4 & 38 & 6 & 4 \\
\hline Eksperimen & \multirow{2}{*}{ Akhir } & 98 & 89 & 56 & 35 & 23 & 19 \\
\hline Kontrol & & 94 & 80 & 16 & 59 & 15 & 9 \\
\hline
\end{tabular}

Tabel 2.Hasil Uji Homogenitas Kemampuan Pemecahan-masalah

\begin{tabular}{ccccccccc}
\hline Kelas & Kemampuan & $\mathbf{N}$ & $\mathbf{X}$ & $\mathbf{S}$ & $\mathbf{S}^{\mathbf{2}}$ & $\mathbf{F}_{\text {hitung }}$ & $\mathbf{F}_{\text {tabel }}$ & Ket \\
\hline Eksperimen & \multirow{2}{*}{ Awal } & 27 & 24 & 12,49 & 156,00 & & & \\
Kontrol & & 28 & 30 & 13,84 & 191,55 & & & \\
\hline
\end{tabular}

Tabel 3.Hasil Uji Normalitas Kemampuan Pemecahan-masalah

\begin{tabular}{ccccc}
\hline Kelas & Kemampuan & $\boldsymbol{x}_{\text {hitung }}^{2}$ & $\boldsymbol{x}_{\text {tabel }}^{\mathbf{2}}$ & Kriteria \\
\hline Eksperimen & \multirow{2}{*}{ Akhir } & 11,2603 & 12,592 & Terdistribusi Normal \\
Kontrol & & 4,7167 & 12,592 & Terdistribusi Normal \\
\hline
\end{tabular}


Tabel 4.Hasil Uji Hipotesis Kemampuan Pemecahan-masalah

\begin{tabular}{ccccc}
\hline Kelas & $\begin{array}{c}\text { Standar Deviasi } \\
(\mathbf{s})\end{array}$ & Varians $\left(\mathbf{s}^{\mathbf{2}}\right)$ & $\mathbf{t}_{\text {hitung }}$ & $\mathbf{t}_{\text {tabel }}$ \\
\hline Eksperimen & 18,11 & 327,97 & 2,02 & 2,00 \\
Kontrol & 14,82 & 219,63 & & \\
\hline
\end{tabular}

\subsection{Pembahasan}

Tujuan ideal implementasi proses berpikir-kausalitik ber-scaffolding dalam pembelajaran adalah mampu meningkatkan kemampuan pemecahan-masalah (KPM) siswa secara maksimal pada seluruh materi yang menjadi pokok bahasan. Apabila tujuan itu belum tercapai maka tetap perlu dicari strategi yang lebih baik dalam membelajarkan siswa menggunakan proses berpikir-kausalitik ini. Hal ini berlaku pula untuk hasil penelitian ini.

Data KPM dalam penelitian ini menggunakan soal uraian dengan mengukur enam indikator yang meliputi: (1) pemahaman (understanding) yaitu kemampuan siswa memahami ide atau gagasan dalam setiap soal; (2) pemilihan (selecting) yaitu kemampuan siswa dalam memilih penyebabpenyebab dan/atau memprediksi berbagai kemungkinan akibat yang dapat terjadi berkenaan dengan kondisi penyebab dalam soal atau fenomena fisika; (3) pembedaan (differentiating) yaitu kemampuan siswa dalam membedakan dan memilih penyebab-penyebab yang dapat menghasilkan suatu akibat tertentu; (4) (determining) penentuan yaitu kemampuan menentukan konsep, prinsip, teori, dan/atau hukum fisika yang dapat digunakan untuk mendukung dalam mengidentifikasi sebuah atau beberapa penyebab sehingga menghasilkan suatu akibat; (5) penerapan (applying) yaitu kemampuan siswa dalam menggunakan konsep, prinsip, teori, dan/atau hukum fisika yang diperlukan dalam mengidentifikasi penyebab-penyebab sehingga menghasilkan suatu akibat tertentu; dan (6) pengidentifikasian (identifying) yaitu kemampuan mengidentifikasi kondisi penyebab-penyebab sehingga dapat menghasilkan suatu akibat tertentu. Seperti yang diperlihatkan dalam Tabel 1, persentase nilai rata-rata KPM pada indikator penerapan (applying) dan pengidentifikasian (identifying) merupakan aspek yang sulit dicapai siswa dibandingkan dengan indikator lainnya. Hal ini dikarenakan kedua indikator tersebut merupakan indikator yang membutuhkan pengetahuan yang cukup tinggi, seperti misalnya pada indikator penerapan yang merupakan kemampuan siswa dalam menggunakan konsep, prinsip, teori, dan/atau hukum fisika yang diperlukan dalam mengidentifikasi penyebab-penyebab sehingga menghasilkan suatu akibat tertentu dan indicator pengidentifikasian yang merupakan kemampuan siswa dalam mengidentifikasi kondisi penyebab-penyebab sehingga dapat menghasilkan suatu akibat tertentu.

Sebagaimana diperlihatkan dalam Gambar 1, capaian akhir KPM siswa pada kelas eksperimen adalah tergolong rendah (54) meskipun peningkatannya cukup signifikan (30) dibandingkan siswa kelas kontrol (15) yang hanya setengahnya. Untuk pengembangan instrumen lebih lanjut perlu dilakukan penyempurnaan didasarkan pada hasil analisis struktur instrumen tersebut, serta didasarkan pada proses pembelajaran itu sendiri.

Sebagaimana dinyatakan Rokhmat (2013 \& 2015) bahwa dalam proses berpikir-kausalitik ber-scaffolding tipe $2 \mathrm{~b}$, pebelajar difasilitasi dengan informasi jenis tabel kausalitas yang harus digunakan, jumlah unsur penyebab maupun akibat, serta sebagian contoh unsur akibat dan penjelasannya. Dalam penelitian ini, telah dimodifikasi adanya penambahan informasi contoh unsur penyebab.

Sekalipun dalam penelitian tersebut instrumen pembelajaran sudah disusun berscaffolding, faktanya capaian akhir KPM pebelajar masih rendah. Dari pengamatan dalam proses pembelajaran diprediksi hal tersebut dikarenakan tiga hal berikut: (1) pemecahan 
masalah multi-akibat termasuk hal baru dan pebelajar selama ini hanya berhadapan dengan masalah mono-akibat (masalah dengan satu jawaban benar), (2) pebelajar selama ini juga terbiasa berhadapan dengan masalah aplikasi soal hitungan tidak terbiasa dengan pemecahan konseptual, dan (3) alokasi waktu normal pembelajaran yang tidak cukup karena pebelajar lebih banyak menggunakan waktu itu untuk mengkaji buku sumber.

Berdasarkan hasil analisis data yang diperoleh selama penelitian menunjukkan bahwa pembelajaran dengan menerapkan proses berpikir kausalitik memberikan pengaruh lebih baik terhadap kemampuan pemecahan masalah fisika siswa. Hal ini dapat disebabkan dalam penerapan proses berpikir kausalitik dilakukan dengan berbantuan Lembar Kerja Siswa (LKS) ber-scaffolding tipe 2b modifikasi. Jadi, selain siswa dilatih berpikir kausalitas dan analitik dalam kegiatan pembelajaran siswa juga ditunjang dengan menggunakan media LKS yang didalamnya diberikan tabel kausalitas dan bantuan-bantuan tahapan berupa sebagian komponen akibat, sebagian komponen penyebab, dan sebagian penjelasan mengenai terjadinya suatu akibat. Oleh karena itu, penelitian ini dapat memberikan penguatan untuk penelitian sebelumnya, diantaranya penelitian yang dilakukan (Rokhmat, dkk. 2012) menyatakan bahwa melalui penerapan proses berpikir kausalitik mampu meningkatkan kemampuan pemecahan masalah fisika mahasiswa.

\subsubsection{Hubungan KPM dan Kreativitas Siswa dalam konteks PBK}

Telah dipaparkan di awal bahwa proses berpikir-kausalitik (PBK) secara umum menggunakan fenomena multi-akibat, yaitu fenomena yang memiliki peluang jawaban benar lebih dari satu. Fenomena jenis ini berbanding lurus dengan pengembangan berpikir kreatif. Kemampuan berpikir ini ditunjukkan oleh tiga indikator, yaitu kelancaran (fluency), fleksibilitas (flexibility), dan/atau keaslian (originality) sebagaimana ketika pebelajar menyelesaikan tugas yang bersifat terbuka (Meyer, 2015) [11]. Sementara, Anwar (2012) menyatakan bahwa selain tiga indikator tersebut, fenomena jenis ini juga menorong pengembangan kemampuan ber-elaborasi [12].

Berkaitan dengan PBK, indikator kelancaran ditunjukkan oleh seberapa banyak dari seluruh jawaban yang berpeluang terjadi dapat diprediksi dan/atau dipilih pebelajar, indikator fleksibilitas diperlihatkan dari tingkat kesulitan jawaban dari fenomena tersebut yang dapat diselesaikan pebelajar. Selanjutnya, indikator keaslian diperlihatkan dari jawaban tambahan yang ditulis pebelajar, dan indikator elaborasi ditunjukkan oleh bagaimana pebelajar membangun idenya dalam mengidentifikasi setiap unsur penyebab sehingga menghasilkan setiap jawaban tersebut.

PBK juga memiliki kemiripan dengan strategi yang telah dikembangkan oleh Escudero (2009). Dalam penelitiannya, mahasiswa program sarjana difasilitasi untuk menginvestigasi semua knowledge (konsep dan teori) yang berpeluang muncul pada fenomena (benda padat dan benda berongga, bola dan silinder, yang menggelinding di atas bidang miring kasar) dengan cara menulis sebanyak mungkin jawaban [13].

\subsubsection{Keterbatasan}

Pengembangan instrumen pembelajaran dengan basis proses berpikir kausalitik dalam penelitian ini masih memiliki kelemahan, baik dari sisi konstruksi instrumen tersebut maupun sisi strategi implementasinya. Dari sisi konstruksi, secara umum, fenomena multi-akibat yang disusun menggunakan deskripsi yang relatif panjang sehingga pebelajar sering kali salah menafsirkan maksudnya. Sementara dari sisi strategi implementasi, pengajar tidak 
memfasilitasi pebelajar untuk menyiapkan diri membaca materi yang akan dibahas di kelas, pembagian kelompok bersifat homogen sehingga terdapat kelompok cenderung mengalami kesulitan dalam mengerjakan tugas.

\subsubsection{Upaya Mengatasi Keterbatasan}

Sebaiknya, beberapa hari sebelum tatap muka di kelas peneliti perlu mempertimbangkan untuk memberikan tugas awal kepada pebelajar. Tugas awal ini diorientasikan untuk membekali pebelajar konsep awal tentang materi yang akan dibahas dalam pembelajaran di kelas. selain itu, dalam menyusun kelompok diskusi penerapan proses berpikir kausalitik mampu meningkatkan kemampuan pemecahan-masalah fisika mahasiswa [5].

\section{KESIMPULAN}

Berdasarkan hasil penelitian dapat disimpulkan bahwa terdapat pengaruh kemampuan pemecahan-masalah fisika siswa antara kelas eksperimen yang diberikan perlakuan berupa penggunaan PBK berbantuan LKS ber-scaffolding tipe $2 \mathrm{~b}$ modifikasi dengan kelas kontrol yang diberikan perlakuan berupa penggunaan model pembelajaran langsung tanpa bantuan LKS. Kemampuan pemecahan-masalah fisika siswa kelas eksperimen lebih tinggi dari kelas kontrol maka dapat dikatakan bahwa penggunaan PBK berbantuan LKS ber-scaffolding tipe $2 \mathrm{~b}$ modifikasi berpengaruh positif terhadap kemampuan pemecahan-masalah kalor disalah satu Sekolah Menengah Atas Negeri di Lombok Tengah.

\section{SARAN}

Penggunaan LKS ber-scaffolding tipe-2b modifikasi dengan pendekatan kausalitik ini patut untuk dipertimbangkan sebagai salah satu tambahan alternatif dalam mengembangkan kemampuan pemecahan masalah fisika siswa. Sebaiknya perlu diteliti lebih lanjut tentang LKS ber-scaffolding dengan tipe-tipe yang lain agar diperoleh informasi mengenai tipe LKS ber-scaffolding yang dapat direkomendasikan untuk dihunakan dalam pembelajaran fisika.

\section{UCAPAN TERIMAKASIH}

Terima kasih penulis ucapkan kepada Bapak Dr. Joni Rokhmat, M.Si., Bapak I Wayan Gunada, S.Si., M.Pd., selaku dosen pembimbing. Terima kasih juga penulis ucapkan kepada bapak H. Muh. Arsil, S.Pd, M.Pd., selaku kepala sekolah yang telah memberikan izin penelitian dan fasilitas yang diberikan, bapak Sri Yuliantini, S.Pd., selaku guru mata pelajaran fisika, dan seluruh siswa kelas X-1 dan X-2 tahun pelajaran 2015/2016 yang telah berpartisipasi dan bekerjasama dalam penelitian ini, serta seluruh pihak yang telah membantu penelitian ini.

\section{DAFTAR PUSTAKA}

[1] Mamin, R. 2008. Penerapan Metode Pembelajaran Scaffolding pada Pokok Bahasan Sistem Periodik Unsur.Jurnal Chemica. 10 (2):55-60.

[2] Mulyono. 2012. Strategi Pembelajaran Menuju Efektivitas Pembelajaran di Abad Global. Malang: UIN Maliki Press.

[3] Markawi, N. 2011.Pengaruh Keterampilan Proses Sains, Penalaran, dan Pemecahanmasalah terhadap Hasil Belajar Fisika.Jurnal Formatif. 3(1): 11-25.

[4] Rokhmat, J., Setiawan, A., dan Rusdiana, N.2012.Pembelajaran Fisika Berbasis Proses Berpikir Kausalitas dan Berpikir Analitik (PBK-BA), Suatu Pembiasaan Berpikir Secara Terbuka.Jurnal Pengajaran MIPA.391-393. 
[5] Rokhmat, J. 2013. Kemampuan Proses Berpikir Kausalitas dan Berpikir Analitik Mahasiswa Calon Guru Fisika. Jurnal Pengajaran MIPA. 78-86.

[6] Rokhmat, J. (2013). Peningkatan Kemampuan Pemecahan Masalah Mahasiswa Calon Guru Fisika melalui Berpikir Kausalitas dan Analitik [The Increase of Problemsolving Ability of Physics Pre-service Student through Causality and Analytic Thinking]. Disertasi Doktor pada Pendidikan IPA. Universitas Pendidikan Indonesia: tidak diterbitkan.

[7] Rokhmat, J. 2015. Penerapan Pendekatan Berpikir Kausalitik Ber-scaffolding dalam meningkatkan KPM Hukum Newton Tentang Gerak.PROSIDING Seminar Nasional FMIPA UNRAM.

[8] Rokhmat, J. (2015). Pengembangan Model Pembelajaran Berbasis Proses Berpikir Kausalitas dan Analisik untuk Meningkatkan Kemampuan Pemecahan Masalah Mahasiswa Calon Guru [The Development of Learning-model Based on Causality and Analytic Thinking to Increase Problem-solving Ability of Pre-service Teacher]. Penelitian Strategis Nasional (laporan tahun pertama). Universitas Mataram: tidak diterbitkan.

[9] Rokhmat, J. (2016). Pengembangan Model Pembelajaran Berbasis Proses Berpikir Kausalitas dan Analisik untuk Meningkatkan Kemampuan Pemecahan Masalah Mahasiswa Calon Guru [The Development of Learning-model Based on Causality and Analytic Thinking to Increase Problem-solving Ability of Pre-service Teacher]. Penelitian Strategis Nasional (laporan tahun kedua). Universitas Mataram: tidak diterbitkan.

[10] Rokhmat, J., Marzuki, Hikmawati, and Verawati, N. N. S. P. (2017). "Instrument Development of Causalitic Thinking Approach in Physics Learning to Increase Problem Solving Ability of Pre-service Teacher." American Institute of Physics Conference Proceeding, 03000-3 - 03000-5.

[11] Meyer, A. A., and Lederman, N. G. (2015). "Creative Cognition on Secondary Science: An exploration of divergent thinking in science among adolescents".International Journal of Science Education. Retrieved from: http://dx.doi.org/10.1080/09500693.2015.1043599.

[12] Anwar, M., N., Aness, M., Kizar, A., Naseer, M., and Muhammad, G. (2012). "Relationship of Creative Thinking with the Academic Achievements of Secondary School Students". International Interdisciplinary Journal of Education, 1(3), 44.

[13] Escudero, C., Moreira, A. M., \& Caballero, C. (2009). "A Research on Undergraduate Students' Conceptualizations of Physics Notions Related to Non-sliding Rotational Motion”. Lat. Am. I Phys. Educ., 3 (1), January, 1-7. 